\title{
Determinants of Enterprises' Capital Structure in Energy Industry: Evidence from European Union
}

\author{
Jacek Jaworski $^{1, *(D)}$ and Leszek Czerwonka ${ }^{2}$ (D) \\ 1 Department of Finance, WSB University in Gdańsk, 80-266 Gdańsk, Poland \\ 2 Faculty of Economics, University of Gdańsk, 80-309 Gdańsk, Poland; leszek.czerwonka@ug.edu.pl \\ * Correspondence: jjaworski@wsb.gda.pl
}

check for updates

Citation: Jaworski, J.; Czerwonka, L. Determinants of Enterprises' Capital Structure in Energy Industry: Evidence from European Union. Energies 2021, 14, 1871. https:// doi.org/10.3390/en14071871

Academic Editors: Beata Zofia Filipiak and Valentina Colla

Received: 1 March 2021

Accepted: 23 March 2021

Published: 28 March 2021

Publisher's Note: MDPI stays neutral with regard to jurisdictional claims in published maps and institutional affiliations.

Copyright: (c) 2021 by the authors. Licensee MDPI, Basel, Switzerland. This article is an open access article distributed under the terms and conditions of the Creative Commons Attribution (CC BY) license (https:// creativecommons.org/licenses/by/ $4.0 /)$.

\begin{abstract}
The aim of the study is to identify the main determinants of the capital structure of energy industry companies in the European Union. The study was based on a panel of 6122 companies from 25 EU countries, operating between 2011 and 2018. The study used multiple regression analysis. We have obtained strong evidence for a positive relationship between corporate debt and tangibility and size, and a negative relationship for profitability and liquidity. The factors that also affect the share of debt in capital have turned out to be growth (positive relationship) and non-debt tax shield (negative relationship), but the statistical significance of these relationships is ambiguous. We have shown that growth of industry business risk is accompanied by an increase in corporate debt and this is a distinguishing feature of the energy industry. For country-specific capital structure determinants, we have obtained strong evidence for the negative relationship between GDP growth, the level of stakeholder rights protection, the degree of capital markets development, and indebtedness of the companies studied. There has been moderate support for the hypotheses of a positive effect of inflation, taxation, and the degree of financial institutions development. Our study has also shown a negative impact of the volume of energy consumption and the share of renewable sources in its production and a positive impact of market monopolization on the indebtedness of companies from the energy industry in the EU.
\end{abstract}

Keywords: capital structure determinants; energy industry; European Union; capital structure theories; indebtedness of energy industry

\section{Introduction}

One of the key industries in today's economy is the energy industry. Numerous studies, including Faisal et al. [1], Mačerinskienè and Kremer-Matyškevič [2], Al-Mulali [3], Simionescu et al. [4], and Hannesson [5] prove the close relationship between energy consumption and GDP growth of economies all over the world. This means that the development of the energy industry is not only an indication of the level of development of a particular economy, but it can also significantly support this process. Due to its relevance to the overall economy, the energy industry is one of the few sectors strictly regulated by governments. The state also dominates as the owner of enterprises in this industry.

Energy policy, and thus the production and distribution of energy, are also of interest to the European Union. The close relationship of the energy policy with the security and energy independence of the community, as well as its impact on the natural environment, have become the basis for regulation at the supranational level. The first decade of the 21st century saw an introduction of changes that have led to a very dynamic change of the current EU energy industry. These changes mainly concern [6]:

- harmonization of energy production regulations in individual member states aimed at unifying the policy of national regulators and their impact on the energy market, and

- $\quad$ setting common directions for technological development related to the wider use of renewable energy sources as more environmentally friendly. 
As part of the adopted priorities, the EU also decided to demonopolize and liberalize the energy market $[7,8]$.

The energy policy at the EU level, maintained for over a dozen years, has resulted in a significant unification of the operating conditions of the energy industry in the member states. The "European Green Deal" [9] adopted in 2020 is a continuation of this policy. However, despite the abovementioned common priorities, there are still differences, mainly manifested in the structure of the market, the amount of consumption, and energy sources in individual countries [10]. The consequences of the qualitative changes taking place in the energy industry in the EU are also changes in its financing.

Decisions concerning the choice of sources of financing and creating the capital structure of enterprises constitute one of the most important areas of modern enterprise management. Therefore, searching for regularities and determinants of these decisions is a frequently undertaken research direction. This research has a rich history and an established position in corporate finance. The study of Modigliani and Miller [11], which presented the first theory on the choice of capital structure and its impact on firm value under perfect market conditions is the key work beginning this strand of research. Since then, several alternative theories have been developed, considering various distortions of the market mechanism. The most popular are (i) trade-off theory [12-15] and (ii) pecking order theory [16-18].

The analysis of capital structure theory and numerous empirical studies have identified a number of factors that influence the financial behavior of firms. These factors are divided into the three following groups [19-21]: (i) company-, (ii) industry-, and (iii) country-specific factors. Firm-specific factors have the widest impact on the capital structure of firms. According to various sources, they explain 60 to $85 \%$ of the variation in corporate debt. On the other hand, country-specific factors explain only 5 to $15 \%$ of this variation. Industry-specific factors account for the remaining 10 to $25 \%$ of the variation in indebtedness of contemporary enterprises.

Despite the energy industry's substantial economic impact, as well as its specific ownership structure, the financial behavior of companies in this industry is relatively rarely studied [22-30]. The indicated research gap becomes particularly relevant for Europe in the context of the common EU energy policy.

The aim of the paper is to identify the main determinants of the capital structure of energy industry companies in the EU countries. The research is focused on identifying classic determinants of capital structure at the company, industry, and country level. In addition, a preliminary research study was carried out on the impact of specific factors for the energy policy that differentiate the operating conditions of enterprises in individual countries. The study was based on a panel of 6122 companies from 25 EU countries, operating in the 2011-2018 period. The study used multiple regression analysis.

Our study mostly confirmed the results of previous studies on firm-specific determinants of capital structure in energy industry:

- We obtained strong evidence for a positive relationship between corporate debt and tangibility and size, and a negative relationship for profitability and liquidity.

- Growth (positive relationship) and non-debt tax shield (negative relationship) were found to be factors that also affect the debt-to-capital ratio, but the statistical significance of these relationships is ambiguous.

The research also provides some new evidence, especially for energy industry:

- We have shown that while similar to other industries, the indebtedness of energy companies increases with decreasing industry financial risk, the opposite is true for industry business risk. An increase in this risk is accompanied by an increase in corporate indebtedness and this is a definite distinguishing feature of the energy industry at least within the EU.

- In the case of country-specific capital structure determinants, we obtained strong evidence for a negative relationship between inflation, GDP growth, the level of 
stakeholder rights protection, the degree of development of capital markets, and the indebtedness of the companies studied.

- There was moderate support for the hypotheses of a positive effect of taxation and the degree of financial institutions development.

- Furthermore, our study found the effect of three factors related to energy production and consumption on the indebtedness of enterprises. This indebtedness decreases with the increase in energy consumption and also with the increase in the share of renewable sources in energy production. However, the larger monopolization of the energy market, the larger indebtedness of companies operating on it.

The paper consists of five parts. The first one presents the most prevalent capital structure theories. It also includes the description of fundamental determinants of enterprises' capital structure with outlining the current state of empirical studies related to firms' financing behavior, especially in the energy industry. Based on that, we have formulated research hypotheses. The second part of the paper describes methods applied in the empirical study and the gathered research material. In the third part of the paper, the results of the research have been presented. Their discussion has been developed in the next section. The conclusions of the research constitute the last part of the paper.

\section{Literature Review and Research Hypotheses}

The concept of Modigliani and Miller is considered to be the first coherent theoretical model concerning the capital structure of companies. In its first version, the authors stated that the cost of capital and hence the market value of a firm, under perfect market conditions, are independent of the structure of capital [11]. This original concept has been later modified by introducing many different inputs into the model (corporate tax, shareholder income taxes, etc.) [31,32].

Criticism of Modigliani and Miller's model, in particular accounting for market distortions arising from the agency theory [33] and the theory of information asymmetry [34], led to the development of further theoretical concepts relating to corporate financial decisions. The trade-off theory and the pecking order theory are most prevalent in the literature.

The first theory is based on the assumption that capital structure results from comparing the costs of financial distress resulting from debt with the benefits of reducing the income tax base. On the one hand, debt increases the risk of bankruptcy (costs) and on the other hand it creates a tax shield (benefits). Financial decisions in this approach are related to determining the optimal ratio of debt to enterprise value. The company gradually aims to achieve the target capital structure by balancing the benefits of the tax shield against the costs related to financial distress [12-15].

The pecking order theory arose from the observation that highly profitable companies are usually characterized by low indebtedness. Detailed analysis of this phenomenon has indicated that companies prefer a certain order of selection of financing sources based on adverse selection. Management, with the greatest knowledge of the company's situation, usually finances its development from the profits generated. External investors have less knowledge of the enterprise. From their point of view, equity participation is riskier than borrowing money. Hence, when the possibilities for self-financing end, companies issue debt and, only as a last resort, increase equity [16-18].

The analysis of the linkage of basic corporate financial data with both described theories of capital structure led to the identification of firm-specific determinants of capital structure. Based on theoretical assumptions, numerous authors such as Harris and Raviv [35], Rajan and Zingales [36], Frank and Goyal [37], and Neves et al. [38] showed that important factors at the company level are as follows: (i) tangibility measured by the share of fixed assets in total assets (TANG), (ii) firm size (SIZE), (iii) firm growth opportunities (GROW), (iv) profitability (PROF), (v) financial liquidity (LIQ), and (vi) non-debt tax shield (NDTS). The direction and strength of the impact of the above factors on corporate debt varies depending on the theoretical assumptions used (see Table 4). 
The research on the identification and determination of the direction and strength of the impact of firm-specific factors on corporate indebtedness has undoubtedly the longest tradition in the empirical studies of capital structure determinants. The literature contains many studies which differ in the set of examined factors, research sample, and method. The results of selected studies are summarized in Appendix A.

Studies conducted for specific countries were subject to meta-analyses $[21,39]$. In their study, Hang et al. [39] included 50 articles from reputable scientific journals and 50 publications from outside the major databases. The authors did not indicate the time range of the selected publications. Their analysis showed that the significant firm-specific factors were TANG, GROW, and PROF. The first of these affected the corporate debt positively, while the next two negatively. On the other hand, Jaworski and Czerwonka [21] meta-analyzed 49 articles published between 1993 and 2017 referring to listed companies from 35 countries. PROF and LIQ turned out to be significant firm-specific factors, both negatively affecting corporate debt.

Appendix A also summarizes the results of cross-sectional empirical studies on firmspecific factors relating directly to EU countries [40-44]. They indicate a large diversity in the relationships between firm-level determinants and debt of the companies studied. This means that they may vary depending on the research sample (place of operation of the studied companies) and the time of the study. The most frequently diagnosed firmspecific factors were TANG, GROW, and PROF. However, considering the directions of the identified relationships, in most studies only PROF showed a negative impact on firm debt.

The last group of empirical findings presented in Appendix A includes papers on firm-specific determinants of capital structure in energy industry [22-24,27,28,45]. They are characterized by less heterogeneity than in the cross-sectional studies. Most of them (four) indicate a negative relationship between PROF and corporate debt. Three studies indicate a statistically significant positive relationship between debt and TANG. Two studies identify a positive effect of SIZE. Two studies also identified a significant effect of LIQ on capital structure. Three studies identify an impact of GROW. However, due to the different directions of the relationship, it is difficult to identify the dominant one in a clear manner. Only one study detects a statistically negative effect of NDTS on the share of debt in the capital of energy companies. It is also worth noting that only two studies include energy industry companies from Europe.

Considering the summarized results on firm-specific factors, the following research hypotheses can be formulated for the EU energy companies (last column in Appendix A):

Hypothesis 1a. An increase in TANG causes an increase in corporate debt.

Hypothesis $\mathbf{1 b}$. SIZE exerts a positive effect on corporate debt.

Hypothesis 1c. A decreasing share of debt in corporate capital structure is affected by increasing PROF.

Hypothesis 1 d. There is a negative effect of LIQ on corporate debt.

Hypothesis 1e. GROW and NDTS are significant factors shaping the capital structure of firms.

Apart from firm-specific determinants, previous research has also identified two groups of external factors. The first of these includes factors relating to the industry in which the company operates, while the second relates to economic characteristics at the country level (macroeconomic and institutional).

Belonging to a particular industry as an external determinant of capital structure was indicated by Harris and Raviv [35], Titman and Wessels [46], and Bradley et al. [47]. According to Ebeh Ezeoha [48], the industry effect is expressed by the common characteristics of the operations performed, scale of operations, growth opportunities, the impact of the same regulations, similar financing strategies, similar opportunities, and threats present 
in particular market. An industry influences the structure of capital primarily through sensitivity of enterprises belonging to this industry to changes in the economic situation. The higher the sensitivity, the greater the aversion to excessive debt [49]. This means that the average indebtedness and the accompanying growth of companies belonging to the industry can be considered as distinguishing features of the industry [50]. The industry is also a determinant of asset structure. On the one hand, asset structure is the result of a firm's response to the industry's business risk (higher business risk may make access to debt more difficult). On the other hand, a higher share of fixed assets in the firm's assets implies a higher collateralization of loans, i.e., the possibility to reduce financial risk and thus increase debt $[51,52]$.

In empirical studies, the industry effect on the capital structure of firms is identified relatively less frequently than firm-specific determinants. Among others, it has been identified by Koralun-Bereźnicka [40] and Hall et al. [53]. The first author, studying data from 3500 small and medium-sized enteprises for 1995 from the UK, showed significant differences in debt between industries. The second one based the study on 5033 observations on firms from 11 EU countries operating between 2000 and 2014. The variable identifying the industry was found to affect firm debt in a significant manner. Frank and Goyal [50] introduced two industry-specific variables into their model, namely median debt and growth of companies operating in that industry. In a study including data from US public companies for the period 1950-2003, they showed that only the first of the industry variables had a significant positive effect on corporate debt. Among others, this variable was also used in studies by Gungoraydinoglu and Öztekin [19] and Jõeveer [20], confirming its positive effect on the share of debt in the capital of companies diagnosed by their predecessors. Gungoraydinoglu and Öztekin [19] did so based on a sample of 15,177 companies from 37 countries operating between 1991 and 2006, while Jõeveer [20] relied on data from the Amadeus database for companies from 9 CEE countries for the period 1995-2002.

Gungoraydinoglu and Öztekin [19], Jõeveer [20], and Frank and Goyal [50] have shown that firms in an industry tend towards a similar financial structure. It is the result of the attrition of capital demand and creditor confidence. Therefore, the median indebtedness of companies operating in a given industry determines their debt capacity, i.e., indirectly the financial risk of the industry as well. The higher it is, the lower the risk. The business risk is another component of industry risk. It is related to competition, the elasticity and changes in demand, product offerings, and, as a result, to changes in operating profits of companies active in a given industry. Studies by Kale et al. [51], Hall et al. [53], and Schwert and Strebulaev [54] have shown that higher business risk can reduce firms' propensity to borrow.

Risk is one of the key factors identified as having a significant impact on the development of the energy industry. This industry, dominated by the state as the owner of companies, is much more vulnerable to business cycles than the companies linked to private capital are. In periods of recession, the state is unwilling to invest in the development of energy infrastructure. This means an increased need for external capital, which in turn increases the financial risk of the industry. By contrast, during growing economic prosperity, an underinvested energy infrastructure that frequently does not match the increased demand for energy, raises the business risk of the industry [55,56]. Hence, it can be expected that the level of both risk components of the energy industry can significantly influence corporate debt:

Hypothesis 2a. Energy industry median debt significantly and positively affects the indebtedness of firms operating in it.

Hypothesis $\mathbf{2 b}$. An increase in the business risk of the industry causes a decrease in the indebtedness of energy companies.

The last group of factors affecting the capital structure of enterprises includes the characteristics of the economy of the country in which they operate. These factors were 
analyzed by Rajan and Zingales [36], Frank and Goyal [50], de Jong et al. [57], Mac An Bhaird and Lucey [58], Psillaki [59], and Graham and Harvey [60]. They can be divided into two groups. The first are factors resulting from the macroeconomic situation of a given economy. The second group of country-specific factors is related to the institutional environment of enterprises. The important macroeconomic factors are as follows:

- GDP growth-faster growing economies create conditions for greater use of debt in corporate financing, but on the other hand, better economic conditions and therefore higher corporate profits make it possible to repay excessive debt;

- inflation rate-higher inflation means higher cost of borrowing and therefore limited use of debt; and

- taxation-a higher degree of fiscalization of the economy encourages greater use of debt as a tax shield.

The most important institutional factors are:

- the degree of the rule of law-better legal protection of stakeholders, and, above all, business owners favor a wider use of equity in business financing;

- the degree of capital market development - the more developed the capital market, the more easily the enterprises issue equity and reduce share of debt in their capital; and

- the degree of development of financial market institutions-the higher degree of development of the banking system and other financial institutions, the wider the access to external sources of financing (debt).

The macroeconomic country-specific factors are the subject of the research of Gungoraydinoglu and Öztekin [19], Jõeveer [20], and Kayo and Kimura [61]. All authors confirmed the negative effect of GDP growth on corporate debt. Gungoraydinoglu and Öztekin [19] and Jõeveer [20] also confirmed the negative effect of inflation. Gungoraydinoglu and Öztekin [19] also diagnosed an increase in corporate debt with an increase in taxation. Similar results were also obtained by Frank and Goyal [50], Booth et al. [62], and Delcoure [63]. For the energy industry, relationships between macroeconomic factors and capital structure were studied only by Škuláňová [25], identifying, similarly to other authors, a negative impact of GDP growth on corporate debt. Taking the above into account, the next research hypotheses can be formulated as follows:

Hypothesis 3a. Energy industry corporate debt decreases with increasing GDP.

Hypothesis $3 b$. Rising inflation causes corporate debt of enterprises in energy industry to decrease.

Hypothesis 3c. Higher taxation of an economy results in higher energy industry corporate debt.

Most authors of studies on country-specific factors emphasize that institutional factors are far more important for corporate capital structure than the macroeconomic ones. The results of the research by Jõeveer [20] and Kayo and Kimura [61] show a negative relationship between the degree of the capital market development and corporate indebtedness in a country. A positive relationship between the degree of development of financial market institutions and debt was shown only by Jõeveer [20]. The relationship between the degree of the rule of law and corporate debt was diagnosed as significant by Jõeveer [20] and Cho et al. [64]. An increase in the protection of owners' rights resulted in an increase in the share of equity in corporate financing and, consequently, the share of debt decreased. This observation is consistent with the findings of Djankov et al. [65] and Bae and Goyal [66]. The relationship between institutional country-specific determinants of capital structure in energy industry companies has not been studied so far. However, based on the research in other industries, it can be assumed that:

Hypothesis 4a. The indebtedness of energy industry companies decreases while the degree of the rule of law increases. 
Hypothesis $\mathbf{4 b}$. The higher the degree of capital market development, the lower the indebtedness of energy industry enterprises.

Hypothesis 4c. A higher degree of development of financial institutions results in higher indebtedness of energy industry enterprises.

The specificity of the activities of energy industry enterprises in the EU creates a premise for linking their financial decisions with subsequent determinants of the capital structure corresponding to the main features differentiating the energy market in individual member states. They concern the three areas mentioned in the introduction [10]: the volume of consumption and the energy sources used, as well as the structure of the energy market in particular country. The impact of these potential factors shaping the financing behavior of energy companies remains unexplored, which justifies the last three research hypotheses:

Hypothesis 5a. The indebtedness of energy companies depends on the level of energy consumption in a particular country.

Hypothesis $\mathbf{5 b}$. There is a significant relationship between the energy sources used in a given country and the debt of energy companies.

Hypothesis $\mathbf{5 c}$. The structure of the energy market in a particular country exerts influence on the indebtedness of energy industry enterprises.

\section{Data and Methodology}

The research data sources are the ORBIS (ORBIS database covers more than 400 million companies and entities across the world, 40 million of these have detailed financial information (https: / / www.bvdinfo.com, accessed 8 December 2020)) database (2020) (corporate financial data), World Bank [67], IMF [68], and Eurostat [69] databases (institutional, macroeconomic, and industry data). We adopted 2011-2018 as the time range of the study. It is the longest time range of data provided by ORBIS. The long-term nature of the study resulted from the assumption that changes in the enterprises' indebtedness especially under the influence of country-specific factors are best observable in the long term. Financial data were taken for entities for which basic financial values, such as fixed assets, current assets, depreciation and amortization, revenue and operating income were available throughout the study period. We also assumed that the equity of the surveyed enterprise had to be positive. The total number of surveyed enterprises is 6122 and the total number of observations is 48,976 . Among additional data (macroeconomic, institutional, and energy specific factors), the data on the variable strength of legal rights index only cover the period 2013-2018, the others cover the period 2011-2018. The enterprises from the European Union countries constitute the geographical scope of the survey. Considering the limitations imposed on the data for the specific items of the financial statements, data were available for enterprises from the following countries: Austria, Belgium, Bulgaria, Czech Republic, Germany, Denmark, Estonia, Spain, Finland, France, Greece, Croatia, Hungary, Ireland, Italy, Lithuania, Luxembourg, Latvia, the Netherlands, Poland, Portugal, Romania, Sweden, Slovenia, and the Slovak Republic. The scope of the study includes energy enterprises. More precisely, these are enterprises in section D and item 35.1 (Electric power generation, transmission, and distribution) based on "The statistical classification of economic activities in the European Community"-NACE Rev. 2. MS Excel (data processing) and Gretl 2020b (econometric models) software were used for the calculations.

Definitions of variables applied in the study are presented in Table 1. The total debt ratio (DR) was used as the measure of the company's capital structure (dependent variable). The items in Table 1 numbered 2 to 7 (TANG, SIZE, GROW, PROF, LIQ, and NDTS) correspond to firm-specific capital structure determinants and they are used to help with verification Hypotheses 1a to 1e. Industry-specific variables are listed in items 8 and 9 
(IND_DR and IND_Beta). They are used for the verification of Hypotheses $2 a$ and $2 b$. Items 10 to 12 (GDP_GROW, INFLAT, TAX_REV) are macroeconomic country-specific factors used for the verification of Hypotheses 3a to 3c. The next three variables (items 13 to 15) are institutional country-specific factors (Legal_rights, FIN_MARK, FIN_INST) and they are intended to help verify Hypotheses 4a to 4c. The last variables in items 16 and 17 (RE_Share and POW_CONS) correspond to the energy characteristics of the economy concerned and they are intended to support the verification of Hypotheses $5 \mathrm{a}$ and $5 \mathrm{~b}$.

Table 1. Variables applied in the study.

\begin{tabular}{|c|c|c|c|}
\hline No. & Variable & Abbreviation & Measures \\
\hline 1. & Capital structure (total debt ratio) & DR & $\frac{\text { total debt }}{\text { total assets }}$ \\
\hline 2. & Assets structure (tangibility) & TANG & $\frac{\text { fixed assets }}{\text { total assets }}$ \\
\hline 3. & Size of the enterprise & SIZE & 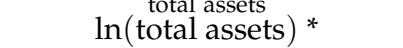 \\
\hline 4. & Growth opportunities & GROW & $\frac{\Delta \text { total assets }}{\text { total assets }}$ \\
\hline 5. & Profitability & PROF & $\frac{\text { EBIT }}{\text { total assets }}$ \\
\hline 6. & Liquidity & LIQ & $\frac{\text { current assets }}{\text { short-term liabilities }}$ \\
\hline 7. & Non-debt tax shield & NDTS & $\frac{\text { depreciation }}{\text { total assets }}$ \\
\hline 8. & Debt ratio median in country/industry & IND_DR & $\begin{array}{l}\text { Median of debt ratio in } \\
\text { particular country } \\
\sum_{i=1}^{n} \frac{\sigma\left(\text { (EBITDA }_{i}\right.}{\text { EBITDA }_{i}} \times \text { Total assets }_{i t}\end{array}$ \\
\hline 9. & Business risk in country/industry & IND_Beta & $\begin{array}{l}\sum_{\mathrm{i}=1}^{\mathrm{n}} \text { Total assetsit } \\
\mathrm{n} \text {-number of enterprises in } \\
\text { particular country }\end{array}$ \\
\hline 10. & Annual growth of GDP & GDP_GROW & $\frac{\text { GDP growth (annual \%) }}{100}$ \\
\hline 11. & Inflation & INFLAT & $\begin{array}{l}\text { Inflation, consumer prices } \\
(\text { annual \%) }\end{array}$ \\
\hline 12. & Tax revenue & TAX_REV & $\begin{array}{c}100 \\
\text { Tax revenue } \\
(\% \text { of GDP }) \\
\end{array}$ \\
\hline 13. & Strength of legal rights index & Legal_rights & $0=\frac{100}{\text { weak to } 12=\text { strong }}$ \\
\hline 14. & Financial markets development index & FIN_MARK & $0=$ weak to $1=$ strong \\
\hline 15. & $\begin{array}{l}\text { Financial institutions development } \\
\text { index }\end{array}$ & FIN_INST & $0=$ weak to $1=$ strong \\
\hline 16. & $\begin{array}{c}\text { Share of renewable energy in gross final } \\
\text { energy consumption }\end{array}$ & RE_Share & $\frac{\text { Percentage RE share }}{100}$ \\
\hline 17. & $\begin{array}{l}\text { Final energy consumption (in TOE) per } \\
1000 \text { inhabitants }\end{array}$ & POW_CONS & $\frac{\text { Final energy consumption }}{\text { population }} \times 1000$ \\
\hline 18. & $\begin{array}{c}\text { Market share of the largest generator in } \\
\text { the electricity market }\end{array}$ & EM_SHARE & $\frac{\text { Percentage largest market share }}{100}$ \\
\hline
\end{tabular}

Source: Own elaboration. * total assets are measured in thousands of euro.

Descriptive statistics of applied variables are presented in Table 2. In case of data based on financial statements, where errors may occur among many records, values which were not between 0 and 1 for DR and TANG variables were excluded and the sample was winsorized to values between 1 and $99 \%$ of distribution. Elimination of outstanding values resulted in arithmetic mean and median values for most of variables being close to each other, except for GROW and LIQ variables, for which significant variation is visible (standard deviations significantly exceed average values).

In order to check whether multicollinearity appears in the studied models, Pearson's linear correlation coefficients were calculated for each pair of variables (Table 3). The values of the coefficients did not reach the level that would indicate a strong or very strong correlation. We have also calculated VIF (variance inflation factor), which should be below 10 , and this is true for all variables. This means that multicollinearity should not be a problem in the panel models analyzed, and the assumed explanatory variables can provide a basis for model estimation [70]. 
Table 2. Descriptive statistics of all variables.

\begin{tabular}{cccccc}
\hline & Mean & Median & S.D. & Min & Max \\
\hline DR & 0.639 & 0.711 & 0.272 & 0.006 & 0.995 \\
TANG & 0.733 & 0.821 & 0.241 & 0.005 & 0.991 \\
SIZE & 7.915 & 7.697 & 1.961 & 3.522 & 14.38 \\
GROW & -0.013 & -0.041 & 0.159 & -0.424 & 1.708 \\
PROF & 0.061 & 0.051 & 0.068 & -0.178 & 0.434 \\
LIQ & 3.833 & 1.395 & 8.424 & 0.037 & 123.3 \\
NDTS & 0.056 & 0.051 & 0.035 & 0.000 & 0.251 \\
IND_DR & 0.701 & 0.718 & 0.108 & 0.063 & 0.882 \\
IND_Beta & 0.255 & 0.261 & 0.109 & -0.297 & 0.626 \\
GDP_GROW & 0.010 & 0.011 & 0.021 & -0.091 & 0.252 \\
INFLAT & 0.012 & 0.012 & 0.012 & -0.017 & 0.058 \\
TAX_REV & 0.191 & 0.185 & 0.053 & 0.113 & 0.281 \\
Legal_rights & 4.100 & 4.000 & 1.915 & 2.000 & 9.000 \\
FM & 0.699 & 0.755 & 0.201 & 0.019 & 0.946 \\
FI & 0.774 & 0.768 & 0.098 & 0.404 & 0.911 \\
RE_Share & 0.186 & 0.167 & 0.088 & 0.029 & 0.546 \\
POW_CONS & 0.493 & 0.430 & 0.195 & 0.175 & 1.290 \\
EM_SHARE & 0.368 & 0.270 & 0.214 & 0.142 & 0.890 \\
\hline
\end{tabular}

Source: Own elaboration.

In the following stage, an investigation of the dependence of the DR variable on firm-specific factors was conducted. For this purpose, econometric models were applied. They were based on:

1. Regression model (ordinary least squares method):

$$
D R_{i t}=\beta_{0}+\beta_{1} \mathrm{TANG}_{i t}+\beta_{2} \mathrm{SIZE}_{i t}+\beta_{3} \mathrm{GROW}_{i t}+\beta_{4} \mathrm{PROF}_{i t}+\beta_{5} \mathrm{LIQ}_{i t}+\beta_{6} \mathrm{NDTS}_{i t}+\varepsilon_{i t}
$$

2. Model with fixed effects:

$$
D R_{i t}=\beta_{0}+\beta_{1} \mathrm{TANG}_{i t}+\beta_{2} \mathrm{SIZE}_{i t}+\beta_{3} \mathrm{GROW}_{i t}+\beta_{4} \mathrm{PROF}_{i t}+\beta_{5} \mathrm{LIQ}_{i t}+\beta_{6} \mathrm{NDTS}_{i t}+\mu_{i t}
$$

3. Model with random effects:

$$
D R_{i t}=\beta_{0}+\beta_{1} \mathrm{TANG}_{i t}+\beta_{2} \mathrm{SIZE}_{i t}+\beta_{3} \mathrm{GROW}_{i t}+\beta_{4} \mathrm{PROF}_{i t}+\beta_{5} \mathrm{LIQ}_{i t}+\beta_{6} \mathrm{NDTS}_{i t}+\varepsilon_{i t}+\mu_{i t}
$$
where:

TANG, SIZE, GROW, PROF, LIQ and NDTS are firm-specific capital structure determinants defined in Table 1,

$\mu_{i t}$-random individual differences,

$\varepsilon_{i t}$-error term.

The ordinary least squares method (OLS) is relevant for homogeneous samples. We applied the Breusch-Pagan test for detecting individual effects. The Hausman test was used to identify fixed or random characteristics of these effects [70]. Verification of Hypothesis 1a and Hypothesis 1e was based on estimation of parameters of the most appropriate model. 
Table 3. Pearson correlation matrix for explanatory variables

\begin{tabular}{|c|c|c|c|c|c|c|c|c|c|c|c|c|c|c|c|c|c|c|}
\hline TANG & SIZE & GROW & PROF & LIQ & NDTS & IND_DR & IND_Beta & GDP_Grow & Inflat & TAX_REV & Legal_Rights & FM & FI & RE_Share & \multicolumn{3}{|c|}{ POW_CONSEM_SHARE } & VIF \\
\hline 1.00 & $\begin{array}{l}0.00 \\
1.00\end{array}$ & $\begin{array}{c}-0.18 \\
0.11 \\
1.00\end{array}$ & $\begin{array}{c}-0.17 \\
0.04 \\
0.06 \\
1.00\end{array}$ & $\begin{array}{c}-0.17 \\
-0.12 \\
-0.01 \\
0.02 \\
1.00\end{array}$ & $\begin{array}{c}0.34 \\
-0.18 \\
-0.29 \\
-0.05 \\
-0.03 \\
1.00\end{array}$ & $\begin{array}{c}-0.04 \\
-0.09 \\
0.00 \\
0.01 \\
-0.02 \\
-0.18 \\
1.00\end{array}$ & $\begin{array}{c}-0.17 \\
-0.03 \\
-0.02 \\
0.04 \\
0.03 \\
-0.09 \\
0.30 \\
1.00\end{array}$ & $\begin{array}{c}0.03 \\
0.00 \\
-0.04 \\
-0.01 \\
0.03 \\
0.12 \\
-0.52 \\
-0.23 \\
1.00\end{array}$ & $\begin{array}{c}-0.02 \\
0.02 \\
0.06 \\
0.04 \\
-0.01 \\
-0.06 \\
0.17 \\
0.00 \\
-0.37 \\
1.00\end{array}$ & $\begin{array}{c}-0.18 \\
0.16 \\
0.04 \\
0.05 \\
-0.06 \\
-0.17 \\
0.23 \\
0.15 \\
-0.15 \\
-0.10 \\
1.00\end{array}$ & $\begin{array}{c}0.17 \\
0.04 \\
0.02 \\
-0.08 \\
0.00 \\
0.12 \\
-0.55 \\
-0.69 \\
0.50 \\
0.13 \\
-0.52 \\
1.00\end{array}$ & $\begin{array}{c}0.01 \\
-0.10 \\
-0.06 \\
-0.10 \\
-0.02 \\
0.03 \\
0.14 \\
0.15 \\
-0.14 \\
-0.10 \\
-0.06 \\
-0.29 \\
1.00\end{array}$ & $\begin{array}{c}0.09 \\
-0.26 \\
-0.08 \\
-0.07 \\
0.03 \\
0.08 \\
0.27 \\
0.02 \\
-0.09 \\
-0.08 \\
-0.32 \\
-0.18 \\
0.63 \\
1.00\end{array}$ & $\begin{array}{c}0.06 \\
0.13 \\
0.02 \\
-0.03 \\
-0.04 \\
0.04 \\
-0.28 \\
-0.57 \\
0.18 \\
-0.12 \\
0.39 \\
0.27 \\
0.07 \\
-0.11 \\
1.00\end{array}$ & $\begin{array}{c}0.10 \\
0.14 \\
0.05 \\
-0.07 \\
-0.03 \\
0.02 \\
-0.13 \\
-0.61 \\
0.11 \\
0.00 \\
0.16 \\
0.35 \\
0.13 \\
0.02 \\
0.79 \\
1.00\end{array}$ & $\begin{array}{c}0.08 \\
-0.04 \\
0.02 \\
0.08 \\
0.08 \\
0.04 \\
0.05 \\
-0.13 \\
0.15 \\
-0.03 \\
-0.17 \\
0.20 \\
-0.53 \\
-0.03 \\
-0.04 \\
0.19 \\
1.00\end{array}$ & $\begin{array}{l}\text { TANG } \\
\text { SIZE } \\
\text { GROW } \\
\text { PROF } \\
\text { LIQ } \\
\text { NDDT } \\
\text { IND_DR } \\
\text { IND_Beta } \\
\text { GDP_Grow } \\
\text { Inflat } \\
\text { TAX_REV } \\
\text { Legal_rights } \\
\text { FM FI } \\
\text { FI } \\
\text { RE_Share } \\
\text { POW_CONS } \\
\text { EM_SHARE }\end{array}$ & $\begin{array}{l}1.3 \\
1.2 \\
1.1 \\
1.1 \\
1.1 \\
1.3 \\
2.3 \\
3.8 \\
1.9 \\
1.3 \\
4.7 \\
5.2 \\
4.6 \\
3.4 \\
5.6 \\
5.0 \\
2.8\end{array}$ \\
\hline
\end{tabular}


The last phase of the examination was to analyze the significance of the impact of the rest of assumed capital structure determinants (Hypothesis $2 a$ to Hypothesis $5 b$ ). For this reason, the recently used panel models were enhanced with the following relating variables: (i) industry-specific factors, (ii) macroeconomic country-specific factors, (iii) institutional indices, and (iv) energy-specific indicators. For the extended models, the Breusch-Pagan and Hausman test were also used to identify individual effects. Since heteroscedasticity and autocorrelation were identified in the models, which could prompt mistaken assessment of the significance of specific variables, heteroscedasticity- and autocorrelation-consistent (HAC) standard errors were applied [71].

Information criteria (Schwarz Bayesian information criterion, Akaike information criterion, and Hannan-Quinn criterion) were applied to find the right specification of the model. The testing procedure was from larger to smaller models. The lower the information criterion value, the better [70].

\section{Results}

Appendix B presents the estimation results of multiple regression models. The results of the Breusch-Pagan and Hausman tests indicate that in all cases, models with individual fixed effects are appropriate for the data analyzed.

Model (1) contains explanatory variables corresponding to firm-specific factors. All factors significantly affect corporate debt. An increase in TANG, SIZE, and GROW causes an increase in corporate debt. When PROF, LIQ, and NDTS increase, the debt decreases.

Models (2) and (3) were extended by variables corresponding to industry-specific factors. Model (2) showed the insignificance of the NDTS variable. Its elimination in model (3) improved all information criteria and did not cause any change in the diagnosed directions of influence of the other factors. The relationship between DR and IND_DR and IND_Beta in both models turned out to be positive.

Model (4) includes all firm-level variables and macroeconomic country-specific factors. In this case, no change in the direction and significance of the impact of firm-specific factors has been found. An increase in GDP_GROW and INFLAT causes a decrease in corporate debt. In contrast, increasing TAX_REV causes an increase in the debt ratio.

Models (5) and (6) contain institutional country-specific determinants in addition to firm-specific factors. In model (5), a non-significant effect on debt was detected for the GROW variable. Other relationships for firm-specific factors are the same as in model (1). After the elimination of the non-significant variable, the sample size changed and the information criteria were not indicative. Model (6) confirmed the negative effect of LEGAL and FIN_MARK on the share of debt in corporate capital and showed a positive relationship for FIN_INST.

Model (7) contains all firm-specific factors supplemented by variables characterizing energy consumption in the country and the share of renewable energy sources. The same effect of firm-specific factors on corporate debt as in model (1) was diagnosed. An increase in RES_SHARE and POW_CONS resulted in a decrease in the share of debt in corporate capital. For EM_SHARE, we can see a positive relationship.

Models (8) and (9) include all assumed explanatory variables and can be treated as robustness checks for the previously discussed models. In model (8), statistically insignificant effects on corporate debt were detected for NDTS, INFLAT, TAX_REV, FIN_INST, RE_SHARE, and POW_CONS. In model (9), from which non-significant variables were eliminated, improvements were found for all three information criteria and all previously diagnosed directions were confirmed for the remaining variables.

Table 4 summarizes the results obtained and compares them with the relationships between debt and the individual determinants of capital structure assumed in the research hypotheses. This table also includes the directions of these relationships resulting from the theories of capital structure. The column "Support" indicates to what extent the obtained results confirm the hypotheses. The criterion for the strength of support was the number of diagnosed significant relationships within the estimated models for individual variables. 
Table 4. Summary of results.

\begin{tabular}{|c|c|c|c|c|c|c|c|c|c|c|}
\hline Factor/Model & 1 & 2 and 3 & 4 & 5 and 6 & 7 & 8 and 9 & Hypotheses & Support & $\begin{array}{l}\text { Trade- } \\
\text { OffTheory }\end{array}$ & $\begin{array}{c}\text { Pecking } \\
\text { Order Theory }\end{array}$ \\
\hline TANG & + & + & + & + & + & + & + & Strong & + & - \\
\hline SIZE & + & + & + & + & + & + & + & Strong & + & $-/+$ \\
\hline PROF & - & - & - & - & - & - & - & Strong & + & - \\
\hline LIQ & - & - & - & - & - & - & - & Strong & + & - \\
\hline NDTS & - & & - & - & - & & $+/-$ & Moderate & - & - \\
\hline IND_DR & & + & & & & + & + & Strong & & \\
\hline GDP_GROW & & & - & & & - & - & Strong & & \\
\hline INFLAT & & & - & & & & - & Moderate & & \\
\hline TAX_REV & & & + & & & & + & Moderate & & \\
\hline LEGAL & & & & - & & - & - & Strong & & \\
\hline FIN_MARK & & & & - & & - & - & Strong & & \\
\hline FIN_INST & & & & + & & & + & Moderate & & \\
\hline RE_SHARE & & & & & - & & $+1-$ & Moderate & & \\
\hline POW_CONS & & & & & - & & $+1-$ & Moderate & & \\
\hline EM_SHARE & & & & & + & + & $+1-$ & Strong & & \\
\hline
\end{tabular}




\section{Discussion}

Our study shows that most of the formulated hypotheses were supported. For Hypotheses 1a-1d concerning firm-specific factors (TANG, SIZE, PROF, and LIQ) we obtained strong support. For the other two determinants (Hypothesis 1e), moderate support was obtained. The obtained results are consistent with previous studies of the energy industry $[24,27,28,45]$ as well as with studies on companies from different industries [21,43]. This shows that the internal factors influencing capital structure impact companies in the energy industry in a similar way, regardless of the region from which the studied companies originate.

The verification of Hypothesis $2 \mathrm{a}$ and Hypothesis $2 \mathrm{~b}$ on industry-specific factors provided different results from those assumed. While Hypothesis $2 \mathrm{a}$, on the association of median DR with corporate debt, was strongly supported, Hypothesis $2 b$ on the influence of industry business risk was not supported. In contrast, in this case, the model showed a statistically significant result with the opposite direction. This means that the higher the business risk of industry, the higher the indebtedness of companies. This is a significant difference compared to studies in other industries [51,54,61].

Hypothesis 3a received strong support regarding the effect of GDP growth on debt (negative relationship), while the effects of inflation and tax burden were revealed only in one model which means that the support for Hypothesis $3 \mathrm{~b}$ and Hypothesis $3 \mathrm{c}$ are moderate. These outcomes confirm the results obtained by Gungoraydinoglu and Öztekin [19], Jõeveer [20], and Kayo and Kimura [61], and imply that energy industry companies respond to changes in macroeconomic country-specific factors in a similar way to companies in other industries.

With regard to the hypotheses concerning the influence of institutional factors, full support was given to the hypotheses concerning the influence of the protection of owners' rights (Hypothesis 4a) and the degree of capital market development on indebtedness (Hypothesis $4 b$ ). In both cases, a negative impact of these factors on corporate indebtedness was diagnosed. These results are consistent with the research findings on the protection of owners' rights [20,64-66] and the research findings on capital market development [20,61]. The positive effect of the development of financial institutions was revealed in two of the three models in our study, indicating moderate support for Hypothesis 4c. Only Jõeveer [20] showed a similar relationship.

Hypotheses $5 \mathrm{a}$ and $5 \mathrm{~b}$ concerning factors related to the structure of energy production and to the volume of energy consumption received moderate confirmation. In both cases, there seems to be a negative relationship between these factors and the indebtedness of energy companies. This means that a higher share of renewable energy sources in a given country causes a decrease in the indebtedness of companies producing the energy. Their indebtedness decreases also when energy consumption increases. The explanation for the second relationship can be found in the theory of finance, according to which an increase in energy consumption causes higher revenues (profits) of companies and increased possibilities of self-financing, and thus a decrease in debt. The reasons for the reduction of corporate debt under the influence of a higher share of renewable energy sources should be sought in (i) greater diversification of energy producers, (ii) greater participation of start-ups in the industry, and (iii) active financial support of the energy transition by the EU. Smaller companies tend to be less willing to borrow money, while start-ups are often mainly financed by equity. In turn, financial support for renewables from EU funds represents an alternative and competitive source of financing for investment projects compared to debt. The strong support for Hypothesis $5 c$ obtained is consistent with this observation. A positive relationship between the share of the largest generators in the electricity market and the indebtedness of energy companies means that the more monopolized the energy industry, the more indebted the companies. 


\section{Conclusions}

Our research confirmed positive relationships between indebtedness of energy enterprises and their tangibility, size, and growth. Profitability, liquidity, and non-debt tax shield exerts a negative influence on the share of debt in the enterprises' capital structure. In this regard, there are no significant differences between the energy industry and the other enterprises in the EU. The diagnosed directions of the influence of firm-specific determinants of capital structure are mostly consistent with the pecking order theory. This observation provides the premise for concluding that this particular theory explains the behavior of energy industry companies. However, this thesis requires further research using methods relevant to testing capital structure theories (dynamic approach).

The diagnosed directions of the influence of industry-specific factors provided different results from the assumed ones. Indebtedness of a particular enterprise negatively depends on financial risk of the industry. However, it increases with the growth of the industry business risk. This is a specific characteristic of the energy industry. We believe that the reasons for this should be sought in the interventionist policy of the EU and member states regarding regulated energy prices and, consequently, fluctuations in the financial results obtained by energy companies. However, the diagnosis of this relationship requires further in-depth research.

The relationship between institutional country-specific determinants of capital structure for companies in the energy industry has not been studied so far. In this respect, the obtained results for the energy industry in the EU countries confirm what has been observed in many regions of the world for diversified samples covering other industries as well. We diagnosed positive relationships between the indebtedness of energy companies and taxation and financial institution development. Negative dependence was detected for GDP growth, inflation, and capital market development.

The diagnosed ambiguous effect of NDTS on the share of debt to capital in the energy industry with a moderate positive effect of taxation is an interesting observation. This implies that in some of the countries, there may be strong fiscal incentives to take on debt in the energy industry despite the strong influence of member states' regulations and the EU financial support on this industry activity. However, this phenomenon requires in-depth research.

We also included in the study three variables, which presents existing differences between energy markets in member states of the EU. This initial research showed that the indebtedness of energy enterprises depends negatively on energy consumption and the share of renewable energy sources in a particular economy. The positive relationship for the monopolization of the energy market were detected. These observations confirm that the common energy policy conducted by the European Union exerts influence on financial behavior of the companies operating in energy industry. It creates the premises for further research as well.

In addition to the recommendations for further research, the results of our study have some practical implications for managers, investors, and regulators. The first quite important point is the confirmation that firm-specific determinants of capital structure derived from the theory are also relevant for energy companies. This means that these firms, although heavily regulated, are, as other firms in the economy, subject to the same forces. The second important issue is the relationship between monopolization in the energy industry and indebtedness of enterprises, where this relationship turned out to be positive. On average, companies in this industry are larger than an average company in the economy. Being large enterprises, they exert a significant influence on the whole economy (including the EU). This means that regulators should bear in mind that greater monopolization in the energy industry equals greater demand for external capital. Conversely, the continuation of the common EU energy policy consisting in the market demonopolization and diversification of energy sources may result in greater financing of enterprises with equity. This may indirectly affect the energy price in the future. 
Limitations of our study include (i) the disproportionate structure of the study sample of companies in relation to the size of the economies, (ii) the limited number of industry and country-specific factors, (iii) the lack of a dynamic approach to the financing behavior of the companies studied.

Author Contributions: Conceptualization, methodology, investigation, writing-original draft preparation, review and editing, J.J. and L.C.; software and data curation, L.C. All authors have read and agreed to the published version of the manuscript.

Funding: This research received no external funding.

Informed Consent Statement: Not applicable.

Data Availability Statement: Data sharing not applicable.

Conflicts of Interest: The authors declare no conflict of interest. 
Appendix A

Table A1. Significant influence of firm-specific factors on indebtedness of enterprises according to selected studies.

\begin{tabular}{|c|c|c|c|c|c|c|c|c|c|c|c|c|c|c|c|}
\hline $\begin{array}{l}\text { Factor/Study } \\
\text { of }\end{array}$ & $\underset{\text { et al. [39] }}{\text { Hang }}$ & $\begin{array}{c}\text { Jaworski } \\
\text { and Czer- } \\
\text { wonka } \\
{[21]}\end{array}$ & $\begin{array}{c}\text { Kędzior } \\
\text { [42] }\end{array}$ & $\begin{array}{c}\text { Mokhova } \\
\text { and } \\
\text { Zinecker } \\
{[41]}\end{array}$ & $\begin{array}{c}\text { Koralun- } \\
\text { Bereźnicka } \\
{[40]}\end{array}$ & $\begin{array}{l}\text { Kenourgios } \\
\text { et al. [43] }\end{array}$ & $\begin{array}{l}\text { Gaud } \\
\text { et al. [44] }\end{array}$ & $\begin{array}{l}\text { Berkman } \\
\text { et al. [22] }\end{array}$ & $\begin{array}{c}\text { Chakrabarti } \\
\text { and } \\
\text { Chakrabarti } \\
\text { [23] }\end{array}$ & $\begin{array}{c}\text { Panicker } \\
{[28]}\end{array}$ & $\underset{[24]}{\text { Ghani }}$ & $\begin{array}{c}\text { Liu \& } \\
\text { Ning [27] }\end{array}$ & $\begin{array}{c}\text { Saeed } \\
{[45]}\end{array}$ & $\begin{array}{c}\text { Škuláňová } \\
{[25]}\end{array}$ & $\begin{array}{c}\text { Research } \\
\text { Hypothe- } \\
\text { ses }\end{array}$ \\
\hline $\begin{array}{l}\text { Research } \\
\text { sample }\end{array}$ & $\begin{array}{l}\text { Meta- } \\
\text { analysis } \\
(100 \\
\text { studies })\end{array}$ & $\begin{array}{l}\text { Meta- } \\
\text { analysis } \\
(49 \\
\text { studies in } \\
35 \\
\text { countries) }\end{array}$ & $\begin{array}{l}\text { A total of } \\
1063 \\
\text { public } \\
\text { compa- } \\
\text { nies from } \\
13 \\
\text { European } \\
\text { countries; } \\
\text { the author } \\
\text { has not } \\
\text { men- } \\
\text { tioned } \\
\text { period for } \\
\text { the study. }\end{array}$ & $\begin{array}{l}\text { Financial } \\
\text { data from } \\
\text { Amadeus } \\
\text { database } \\
\text { for } 27 \mathrm{EU} \\
\text { countries } \\
\text { for the } \\
\text { years } \\
2006- \\
2011 .\end{array}$ & $\begin{array}{l}\text { Financial } \\
\text { data from } \\
\text { BACH- } \\
\text { ESD } \\
\text { database } \\
\text { for 11 EU } \\
\text { countries } \\
\text { in the } \\
\text { years } \\
2010- \\
2014 .\end{array}$ & $\begin{array}{l}\text { A total of } \\
1120 \text { com- } \\
\text { panies } \\
\text { from SME } \\
\text { sector } \\
\text { listed in } \\
28 \mathrm{EU} \\
\text { countries } \\
\text { in the } \\
\text { years } \\
2005- \\
2015 .\end{array}$ & $\begin{array}{l}\text { A total of } \\
5000 \text { firms } \\
\text { from } 13 \\
\text { EU } \\
\text { countries } \\
\text { for the } \\
\text { period } \\
1988- \\
2000 .\end{array}$ & $\begin{array}{l}\text { A total of } \\
79 \\
\text { European } \\
\text { enter- } \\
\text { prises } \\
\text { from the } \\
\text { energy } \\
\text { industry } \\
\text { operating } \\
\text { in years } \\
2009- \\
2012 \text {. }\end{array}$ & $\begin{array}{l}\text { A total of } \\
141 \text { com- } \\
\text { panies } \\
\text { from the } \\
\text { energy } \\
\text { industry } \\
\text { listed on } \\
\text { Bombay } \\
\text { Stock } \\
\text { Exchange } \\
\text { in years } \\
2006- \\
2017 .\end{array}$ & $\begin{array}{l}\text { Three } \\
\text { Indian en- } \\
\text { terprises } \\
\text { from the } \\
\text { energy } \\
\text { industry } \\
\text { operating } \\
\text { in years } \\
2004- \\
2008 \text {. }\end{array}$ & $\begin{array}{l}\text { Twenty } \\
\text { listed } \\
\text { compa- } \\
\text { nies in } \\
2004-2008 \\
\text { from } \\
\text { Pakistan. }\end{array}$ & $\begin{array}{l}\text { A total of } \\
25 \text { electric } \\
\text { power } \\
\text { listed } \\
\text { compa- } \\
\text { nies from } \\
\text { China in } \\
\text { the years } \\
2002- \\
2007 \text {. }\end{array}$ & $\begin{array}{l}\text { A total of } \\
28 \text { compa- } \\
\text { nies listed } \\
\text { in the } \\
\text { energy } \\
\text { sector on } \\
\text { the } \\
\text { Karachi } \\
\text { Stock } \\
\text { Exchange } \\
\text { in years } \\
\text { 2001- } \\
2005 \text {. }\end{array}$ & $\begin{array}{l}\text { A total of } \\
2820 \\
\text { energy } \\
\text { compa- } \\
\text { nies from } \\
\text { the } \\
\text { Visegrad } \\
\text { Group } \\
\text { operating } \\
\text { in the } \\
\text { years } \\
2009- \\
2017 .\end{array}$ & $\begin{array}{l}\text { Claims de- } \\
\text { veloped } \\
\text { on } \\
\text { previous } \\
\text { studies. }\end{array}$ \\
\hline TANG & + & & + & $+/-$ & - & + & + & + & + & & + & & + & & + \\
\hline GROW & - & & - & $+/-$ & - & + & - & & - & & + & & + & & $\begin{array}{l}+ \\
+1-\end{array}$ \\
\hline & - & - & - & - & + & - & & + & - & & - & - & - & $+1-$ & \\
\hline $\begin{array}{l}\text { LIQ } \\
\text { NDTS }\end{array}$ & & - & & $+1-$ & + & & $+\overline{1}$ & - & & - & & - & & $+1-$ & $+\overline{1-}$ \\
\hline
\end{tabular}




\section{Appendix B}

Table A2. Results of model estimations.

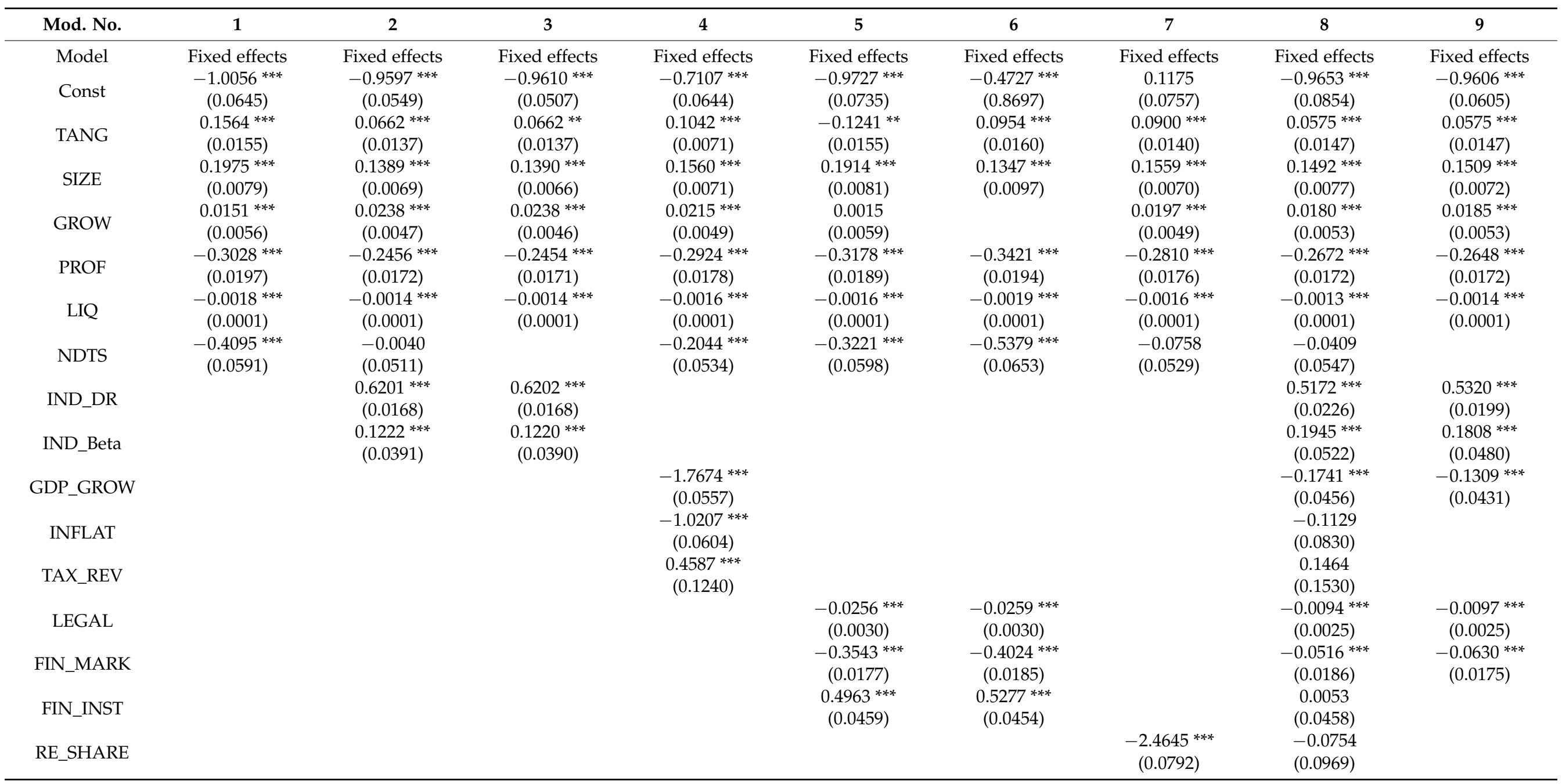


Table A2. Cont.

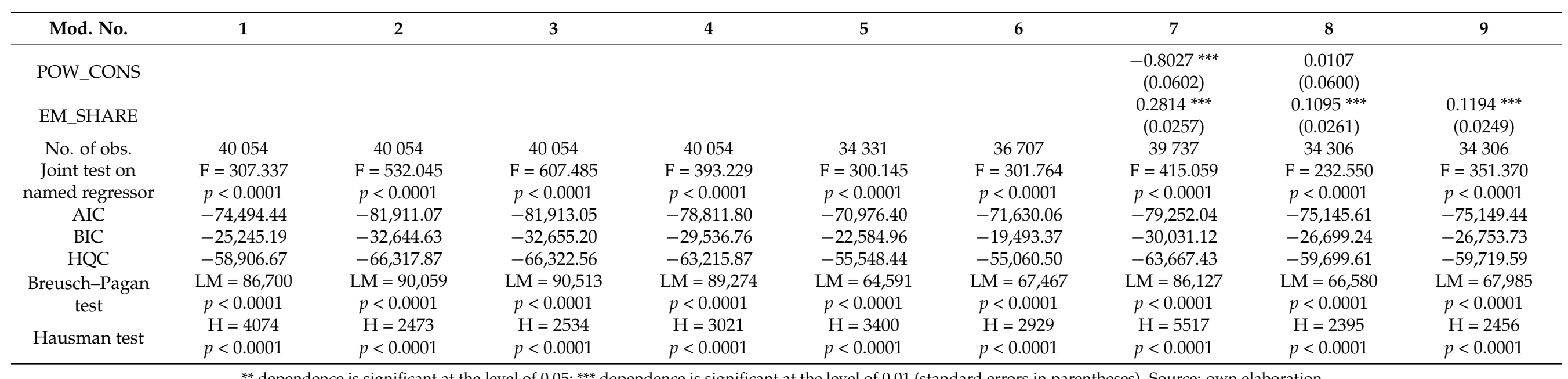

** dependence is significant at the level of $0.05 ; * * *$ dependence is significant at the level of 0.01 (standard errors in parentheses). Source: own elaboration. 


\section{References}

1. Faisal; Tursoy, T.; Resatoglu, N.G. Energy Consumption, Electricity, and GDP Causality; The Case of Russia, $1990-2011$. Procedia Econ. Financ. 2016, 39, 653-659. [CrossRef]

2. Mačerinskienè, I.; Kremer-Matyškevič, I. Assessment of lithuanian energy sector influence on GDP. Montenegrin J. Econ. 2017, 13, 43-59. [CrossRef]

3. Al-Mulali, U. GDP growth—Energy consumption relationship: Revisited. Int. J. Energy Sect. Manag. 2014, 8, 356-379. [CrossRef]

4. Simionescu, M.; Bilan, Y.; Krajňáková, E.; Streimikiene, D.; Gędek, S. Renewable energy in the electricity sector and gdp per capita in the European Union. Energies 2019, 12, 2520. [CrossRef]

5. Hannesson, R. Energy and GDP growth. Int. J. Energy Sect. Manag. 2009, 3, 157-170. [CrossRef]

6. Black, J. European Union energy regulation. In International Regulatory Co-Operation: Case Studies; OECD: Paris, France, 2013; Volume 2, pp. 21-50. [CrossRef]

7. Joskow, P.L. Electricity Market Liberalization: Lessons Learned. Energy J. 2002, 29, 9-41. [CrossRef]

8. Streimikiene, D.; Bruneckiene, J.; Cibinskiene, A. The review of electricity market liberalization impacts on electricity prices. Transform. Bus. Econ. 2013, 12, 40-60.

9. European Commission A European Green Deal. Available online: https://ec.europa.eu/info/strategy/priorities-2019-2024/ european-green-deal_en\#documents (accessed on 15 January 2021).

10. Gunst, A.; Luther-Jones, N.; Cieslarczyk, M. The Energy Regulation and Markets Review. In The Energy Regulation and Markets Review, 9th ed.; Schwartz, D.L., Ed.; Law Business Research: London, UK, 2020.

11. Modigliani, F.; Miller, M.H. The cost of capital, corporation finance and the theory of investment. Am. Econ. Rev. 1958, 48, 261-297.

12. Baxter, N.D. Leverage, risk of ruin and the cost of capital. J. Financ. 1967, 22, 395-404. [CrossRef]

13. Kim, E.H. A Mean-Variance Theory of Optimal Capital Structure and Corporate Debt Capacity. J. Financ. 1978, 33, 45-63. [CrossRef]

14. Kraus, A.; Litzenberger, R.H. A State-preference Model of Optimal Financial Leverage. J. Financ. 1973, 28, 911-922. [CrossRef]

15. Scott, J.H. A Theory of Optimal Capital Structure. Bell J. Econ. 1976, 7, 33-54. [CrossRef]

16. Myers, S.C. The Capital Structure Puzzle. J. Financ. 1984, 39, 574-592. [CrossRef]

17. Myers, S.C.; Majluf, N.S. Corporate financing and investment decisions when firms have information that investors do not have. J. Financ. Econ. 1984, 13, 187-221. [CrossRef]

18. Klein, L.S.; O’Brien, T.J.; Peters, S.R. Debt vs. equity and asymmetric information: A review. Financ. Rev. 2002, 37, 317-349. [CrossRef]

19. Gungoraydinoglu, A.; Öztekin, Ö. Firm- and country-level determinants of corporate leverage: Some new international evidence. J. Corp. Financ. 2011, 17, 1457-1747. [CrossRef]

20. Jõeveer, K. Firm, country and macroeconomic determinants of capital structure: Evidence from transition economies. J. Comp. Econ. 2013, 41, 294-308. [CrossRef]

21. Jaworski, J.; Czerwonka, L. Meta-study on relationship between macroeconomic and institutional environment and internal determinants of enterprises' capital structure. Econ. Res. Istraz. 2019, 32, 2614-2637. [CrossRef]

22. Berkman, A.N.; Iskenderoglu, O.; Karadeniz, E.; Ayyildiz, N. Determinants of Capital Structure: The Evidence from European Energy Companies. Int. J. Bus. Adm. 2016, 7. [CrossRef]

23. Chakrabarti, A.; Chakrabarti, A. The capital structure puzzle—Evidence from Indian energy sector. Int. J. Energy Sect. Manag. 2019, 13, 2-23. [CrossRef]

24. Ghani, K. Determinants of Capital Structure: A Case of Listed Energy Sector Companies in Pakistan. J. Indep. Stud. Res. Soc. Sci. Econ. 2010, 8, 107-115. [CrossRef]

25. Škuláňová, N. Impact of Selected Determinants on the Choice of Sources of Financing in the Energy Companies of the Visegrád Group. Soc. Tyrim. Soc. Res. 2018, 41, 101-111. [CrossRef]

26. Sinha, A. An Enquiry into Effect of Capital Structure on Firm Value: A Study of Power Sector Companies in India. Parikalpana KIIT J. Manag. 2017, 13, 107. [CrossRef]

27. Liu, Y.; Ning, X. Empirical Research of the Capital Structure Influencing Factors of Electric Power Listed Companies. Int. J. Mark. Stud. 2009, 1, 43-49. [CrossRef]

28. Panicker, S. Capital Structure Determinants for Sustained Performance in The Energy Sector of India. Int. J. Res. Commer. Manag. 2013, 4, 77-81.

29. Šeligová, M. The impact of selected financial indicators related to the structure of funding sources on corporate liquidity in energy sector in the Czech Republic and slovak republic. Sci. Pap. Univ. Pardubic. Ser. D Fac. Econ. Adm. 2018, 25, $223-234$.

30. Tailab, M.M.K. The Effect of Capital Structure on Profitability of Energy American Firms. Int. J. Bus. Manag. Inventig. 2014, 3, 54-61.

31. Modigliani, F.; Miller, M.H. The Cost of Capital, Corporation Finance, and the Theory of Investment: Reply. Am. Econ. Rev. 1959, 49, 655-669.

32. Modigliani, F.; Miller, M.H. Corporate Income Taxes and the Cost of Capital: A Correction. Am. Econ. Rev. 1963, 53, $433-443$. 
33. Jensen, M.C.; Meckling, W.H. Theory of the Firm: Managerial Behavior, Agency Costs and Ownership Structure. J. Financ. Econ. 1976, 3, 305-360. [CrossRef]

34. Leland, H.E.; Pyle, D.H. Informational Asymmetries, Financial Structure, and Financial Intermediation. J. Financ. 1977, 32, 371-387. [CrossRef]

35. Harris, M.; Raviv, A. The Theory of Capital Structure. J. Financ. 1991, 46, 297-355. [CrossRef]

36. Rajan, R.G.; Zingales, L. What Do We Know about Capital Structure? Some Evidence from International Data. J. Financ. 1995, 50, 1421-1460. [CrossRef]

37. Frank, M.Z.; Goyal, V.K. Trade-Off and Pecking Order Theories of Debt. In Handbook of Corporate Finance: Empirical Corporate Finance; Eckbo, E.B., Ed.; Elsevier/North: Amsterdam, The Netherlands, 2005; pp. 135-202. ISBN 9780444532657.

38. Neves, M.; Serrasqueiro, Z.; Dias, A.; Hermano, C. Capital structure decisions in a period of economic intervention: Empirical evidence of Portuguese companies with panel data. Int. J. Account. Inf. Manag. 2020, 28, 465-495. [CrossRef]

39. Hang, M.; Geyer-Klingeberg, J.; Rathgeber, A.W.; Stöckl, S. Measurement matters-A meta-study of the determinants of corporate capital structure. Q. Rev. Econ. Financ. 2018, 68, 211-225. [CrossRef]

40. Koralun-Bereźnicka, J. Determinants of Capital Structure Across European Countries. In Contemporary Trends and Challenges in Finance; Jajuga, K., Locarek-Junge, H., Orlowski, L.T., Eds.; Springer International Publishing AG: Cham, Switzerland, 2018; pp. 199-209, ISBN 9783319762289.

41. Mokhova, N.; Zinecker, M. The determinants of capital structure: The evidence from the European Union. Acta Univ. Agric. Silvic. Mendel. Brun. 2013, 61, 2533-2546. [CrossRef]

42. Kędzior, M. Capital structure in EU selected countries-Micro and macro determinants. Argum. Oeconomica 2012, 28 , 69-117.

43. Kenourgios, D.; Savvakis, G.A.; Papageorgiou, T. The capital structure dynamics of European listed SMEs. J. Small Bus. Entrep. 2019, 1-18. [CrossRef]

44. Gaud, P.; Hoesli, M.; Bender, A. Debt-Equity Choice in Europe. Int. Rev. Financ. Anal. 2007, 16, 201-222. [CrossRef]

45. Saeed, A. The Determinants of Capital Structure in Energy Sector; School of Management Blekinge Institute of Technology: Karlshamn, Sweden, 2007.

46. Titman, S.; Wessels, R. The Determinants of Capital Structure Choice. J. Financ. 1988, 43, 1-19. [CrossRef]

47. Bradley, M.; Jarrell, G.A.; Kim, E.H. On the Existence of an Optimal Capital Structure: Theory and Evidence. J. Financ. 1984, 39, 857-878. [CrossRef]

48. Ebeh Ezeoha, A. Firm versus industry financing structures in Nigeria. Afr. J. Econ. Manag. Stud. 2011, 2, 42-55. [CrossRef]

49. Kim, T.; Barrett, J. Recession Lessons. An L.E.K. Supplement to The Wall Street Journal Shareholder Scoreboard; L.E.K. Consulting LLC: Boston, MA, USA, 25 February 2002.

50. Frank, M.Z.; Goyal, V.K. Capital structure decisions: Which factors are reliably important? Financ. Manag. 2009, 38. [CrossRef]

51. Kale, J.R.; Noe, T.H.; Ramirez, G.G. The Effect of Business Risk on Corporate Capital Structure: Theory and Evidence. J. Financ. 1991, 46, 1693-1715. [CrossRef]

52. Baum, C.F.; Caglayan, M.; Rashid, A. Capital structure adjustments: Do macroeconomic and business risks matter? Empir. Econ. 2017, 53, 1463-1502. [CrossRef]

53. Hall, G.; Hutchinson, P.; Michaelas, N. Industry effects on the determinants of unquoted SMEs' capital structure. Int. J. Econ. Bus. 2000, 7, 297-312. [CrossRef]

54. Schwert, M.; Strebulaev, I.A. Capital Structure and Systematic Risk. Rock Cent. Corp. Gov. Work. Pap. Ser. 2014, 1-33. [CrossRef]

55. De Marco, A.; Mangano, G. Risk factors influencing the debt leverage of project financing initiatives in the energy industry. Int. J. Energy Sect. Manag. 2017, 11, 444-462. [CrossRef]

56. Rehme, J.; Nordigarden, D.; Cicksand, D. Public policy and electrical-grid sector innovation. Int. J. Energy Sect. Manag. 2015, 9, 565-592. [CrossRef]

57. De Jong, A.; Kabir, R.; Nguyen, T.T. Capital structure around the world: The roles of firm- and country-specific determinants. J. Bank. Financ. 2008, 32, 1954-1969. [CrossRef]

58. Mac An Bhaird, C.; Lucey, B. Culture's influences: An investigation of inter-country differences in capital structure. Borsa Istanb. Rev. 2014, 14, 1-9. [CrossRef]

59. Psillaki, M.; Dasaklakis, N.; Daskalakis, N. Are the determinants of capital structure country or firm specific? Small Bus. Econ. 2009, 33, 319-333. [CrossRef]

60. Graham, J.R.; Harvey, C.R. The theory and practice of corporate finance: Evidence from the field. J. Financ. Econ. 2001, 60, 187-243. [CrossRef]

61. Kayo, E.K.; Kimura, H. Hierarchical determinants of capital structure. J. Bank. Financ. 2011, 35, 358-371. [CrossRef]

62. Booth, L.; Aivazian, V.; Demirguc-Kunt, A.; Maksimovic, V. Capital structures in developing countries. J. Financ. 2001, 56, 87-130. [CrossRef]

63. Delcoure, N. The determinants of capital structure in transitional economies. Int. Rev. Econ. Financ. 2007, 16, 400-415. [CrossRef]

64. Cho, S.S.; El Ghoul, S.; Guedhami, O.; Suh, J. Creditor rights and capital structure: Evidence from international data. J. Corp. Financ. 2014, 25, 40-60. [CrossRef]

65. Djankov, S.; McLiesh, C.; Shleifer, A. Private credit in 129 countries. J. Financ. Econ. 2007, 84, 299-329. [CrossRef]

66. Bae, K.H.; Goyal, V.K. Creditor rights, enforcement, and bank loans. J. Financ. 2009, 64, 823-860. [CrossRef]

67. World Bank Databases. Available online: https:// worldbank.org (accessed on 21 January 2021). 
68. International Monetary Fund IMF Databases. Available online: https:/ /imf.org (accessed on 21 January 2021).

69. Eurostat. Available online: https:/ / ec.europa.eu/eurostat (accessed on 21 January 2021).

70. Greene, W.H. Econometric Analysis; Prentice Hall: Upper Saddle River, NJ, USA; New York, NY, USA, 2003.

71. Gujarati, D.N.; Porter, D.C. Basic Econometrics, 5th ed.; McGraw-Hill/Irwin: New York, NY, USA, 2009 ; ISBN 9780073375779. 